\title{
Da'wah in the early era of Islam: A review of the Prophet's Da'wah Stratigies
}

\author{
SaadJaffar \\ Lecturer of Islamic studies, Department of Pakistan Studies, Abbottabad \\ University of Science and Technology, Abbottabad \\ Nasir Ali khan \\ Assistant prof, Comsats University Islamabad,Abbottabad campus \\ DOI: (https://doi.org/10.46568/ihya.v21i2.120)
}

\section{Abstract}

The life of Holy Prophet (PBUH) is a beacon of light not only for Muslims but for all of humanity. There is no such aspect of life for which we do not have guidance from the life of Holy Prophet (PBUH). Whether it is personal life or social life. One of these aspects is the Da'wah strategy of the Holy Prophet (PBUH) in Makki era. This article elaborates the Holy Prophet's (PBUH) strategies adopted for the preaching of the Islam during the Makki era. The basic elements of his missionary strategies such as the way of argumentations, parlance and dialects are made the subject of discussion. It highlights the diverse and distinct communication strategies to make the message of Islam intelligible to the common people even, which include: common values, courtesy, non-violence, intellectual stature of the audience, evolutionary process, the psychological intelligibility of addressee, sense of responsibility and proportionality, capacity to perform missionary activity, intimacy with newly converts, concealment of the faith, migration, and strong assertion of faith. The methodology deployed in construing this discourse is descriptivecum-analytical.

Key words: Figh-ul-Seerah, Da'wah strategy, Makki era, Mission, Islam, Mannerism, Parlance, Migration, Non-violence, Conversion.

\section{Introduction:}

What is the proof of the greatness and exaltation of the Holy Prophet (saw) that the Creator of the universe Himself praised him. The creator himself sends greetings to Him and expresses His glory by saying "فاتبعونى", He made His obedience obligatory, by saying "يحبكم الله gave you a certificate of affections and by saying "وانا له لخفظون "he gave the status of safety to your teachings. He said that the words and deeds of your miraculous life were recited by the Companions and made a model for His way of life. Every aspect of His life is a beautiful bouquet of wisdom and admonition for us, by following which we can improve our world and the hereafter. His social reforms and bring the society to the Path of Allah Almighty are exemplary. Da'wah and preaching of Islam was one of his official duties and for the sake of this $d a^{\prime}$ wah and preaching and a Lifelong Mission. He endured great hardships and sufferings, and especially in His own country and in His beloved homeland of Makkah, also faced the atrocities of His people of the area. As the conspiracies and insurrections of his own and others become more serious in the same severity knots of wisdom and prudence of holy prophet become untied, firm and determined. In these difficult circumstances of His Makki life, the Prophet 
(peace and blessings of Allah be upon him) devised comprehensive strategies of da'wah, preaching and exposed the beautiful aspects of politics and rule of Islam. Humble, True, Loving and Caring Hazrat Muhammad (SAW) continuously remained firm, by verbal and non-verbal communication remained successful in His mission of da' wah with superb patience and brought it to completion. His military and civic strategies changed the lives of the people of Makkah but also the whole Ummah. At first invite people to the oneness of Allah Almighty and bring them under the flag of Islam was a very challenging task, but due to His high moral values and benign behavior, He did it. All the strategies He used during His Makki Life to call the people to the truth are exemplary. He used His wisdom and intellect to call people to Allah according to their mentality and consciousness. The patience with which He carried out His mission and responded evil with good was the main factor of His Success in Da'wah. By avoiding practical confrontation, advanced his mission by adopting different strategies and especially His true leadership not only altered the shape and structure of Da'wah but also provided the basic principles to the faith of Muslim Ummah.

\subsection{The literal meaning of invitation (Da'wah) is:}

Imam Ragib Asfahani says:

"Inviting, persuading, calling and voicing1"

$$
\text { "الدعا الى الشىء الحث على قصده" }
$$

Summoning something, urging its intention

The meaning of da' wah according to Shari'a:

" That is the message which Allah gave to mankind through His messengers, saying: Believe in the true religion (i.e. Islam). ${ }^{\prime \prime}$

\subsection{The literal meaning of preaching:}

According to Ibn Manzor Africi:

"To convey something to someone, to convey news, etc., to inform4"

\subsection{Terminological meaning of preaching:}

" Spread the goodness and virtue of what we consider good to other peoples, nations and countries and invite them to accept it. ${ }^{\text {" }}$

\subsection{Synonyms for preaching:}

"One word is "Andaz" which means to warn and beware, the other word is "invitation" which means to call and invoke and the third word is "tazkir" which means reminder and admonition. 6"

\subsection{Meaning of strategy:}

" Tact, ingenuity, foresight, policy, national interest7"

The Author of Noor ul Lughat Says:

"Strategy (according to the occasion) Expediency (according to the requirements of the situation) Policy, national strategy. The knowledge in which the state of and livelihood management is mentioned to full extend"8

According to Encyclopedia of Britannica:

"In 18th century and early 19th centuries, however, when the term first became current and apparent, strategy denoted the art of projecting and directing campaigns and the movement and dispositions of military forces in war ${ }^{9}$

Strategy is translated from "policy" in the Arabic dictionary and also from tact.

According to Urdu dictonary: 
"In English for the word "Hikmat" the word is used "strategy".

Strategy, in warfare, is the science and arts of employing all the military, economic, political and other resources of the nation to achieve the objects and economic mobilization for warfare. $^{10}$

According to long man dictionary:

"Strategy: The Art of planning in Advance the movements of army or forces in war"11

Strategy is the name of adopting a wise, prudent and expedient attitude, action or deed according to time and place, individuals and circumstances. Whether this attitude is used in daily life, the field of da'wah, preaching it may be used in the battlefield. It is a strategy.

\subsection{The Qur'anic Principles of Prophetic Strategy of Da'waa:}

Since the teacher of the Prophets is Allah Almighty Himself, the humor of the Prophets is influenced by the divine teachings of the Divine Essence. This is the reason that when Hazrat Ayesha (RA) was asked about the noble character of the Holy Prophet (SAW), Siddiqah Kainat said:

$$
\text { "ان خلق رسول الله }
$$

"The Holy Qur'an is the evidence of the morality of the holy Prophet". It was narrated in another Hadith:

$$
\text { "13" }
$$

"My Lord taught me then made my literature excellent"

Therefore, it seems very appropriate to mention the Qur'anic and divine teachings and principles of $\mathrm{Da}^{\prime}$ wah and preaching in a manner that is appropriate to the subject. Allah Almighty says in Quran:

$$
\text { " ادع إلى سبيل ربك بالحكمة والموعظة الحسنة وجادهم بالتي هي أحسن إن ربك هو أعلم بمن ضل عن سبيله وهو أعلم }
$$

O Prophet! Call the people to the Way of your Lord with wisdom and good counsel, and argue with them in a way that is best. I know them well. And your Lord knows best those who stray from His Path, and He knows best those who follow the path.

These three principles of preaching and Da'wah have been taught to Muslims. Which are usually used in logical reasoning?

1. Wisdom

2. Intellectuality

3. Good communication skills

This way of dealings is described by the scholars. These three principles are the same, which are usually used in logical reasoning. That is, one argument, another rhetoric, a third dialectic. These are the three ways in which a person proves his point to another.

"Sabeel Rabbik" means Islam, "Wisdom" means Divine Revelation, and "AlMu'izzah Al-Hasna" means the lessons and instructive events mentioned in the Holy Qur'an. These are the lessons and instructive incidents mentioned in the Qur'an, and the meaning of the argument is to adopt the method which is better than the other method. Forgive the painful humiliation of your disbelievers and do not obey them in your duty of preaching the message of your Lord and don't believe in disbelievers. 
Ihyā'al 'ulüm, July-Dec 2021, Volume: 21, Issue: 2

Wisdom refers to the method of invitation in which measures are taken which affect the heart of the addressee, taking into can account the circumstances of the addressee. Good advice means that the title should be soft, and "argument with goodness" means that if it turns into debate, it should also be free from intensity and violence and blaming and injustice on the addressee.

However, Allama Aloosi said:

"Wisdom and good sermons are the principles of $D a^{\prime} w a h$, but argument is not one of the principles of $\mathrm{Da}^{\prime}$ wah, although it is needed in $\mathrm{Da}^{\prime}$ wah and preaching"15

$$
\text { "ادع الى سبيل ربك بالحكمة والموعظة الحسنةوجادلم بالتى هى احسن "16 }
$$

O Prophet! Call the people to the Way of your Lord with wisdom and good counsel, and argue with them in a way that is best.

\subsection{Five Qur'anic Principles of Prophetic mode of Da'wah:}

" The message of Allah is a great fountain of truth which gradually irrigates the earth near it with its natural speed, then onwards and then onwards till it reaches the edges of the earth. The Prophet (peace and blessings of Allah be upon him) was commanded to preach with the same degree. ${ }^{17 "}$

First of all, he was ordered to warn and preach to his family and relatives:

$$
\text { "18" اوانذر عشيرتك الاقربين }
$$

\section{O Prophet, warn your relatives}

When this verse was revealed, he ascended Mount Safa and called out to the tribes of Quraish, such as Fahr and Bani 'Adi, until they came together. Those who could not reach themselves sent their men. He said: If I tell you that an army on this side of the valley wants to attack you, will you confirm me? They said: We have no experience of misrepresentation about you. He said: I am only going to warn you of the punishment that is to come. Abu Lahab said! Your death gathered us together for it, so these verses were revealed to him at that time. ${ }^{19}$ Allah Almighty says in Quran:

$$
\text { "بت يدا ابى لب وتب- "20" }
$$

\section{"Both hands of Abu-lahab would be destroyed"}

Now this scope of preaching is to be extended to Makkah and its surrounding:

$$
\text { "21" }
$$

In order to warn the people of Makkah and the people around Makkah, the Prophet (peace and blessings of Allah be upon him) stayed in Makkah and warned the people around Makkah. He awakened and alerted the people around him. During the Hajj season, he went to every tribe of Arabia and conveyed the message of truth. At the same time, his voice reached as far as Yemen and Ethiopia. And people came to him in search of truth. ${ }^{22}$ Under this command, he travels to Taif and faced the disbelievers and enemies.

"The festivals of Okaz, Majna and Zhu al-Majaz were very popular in Arabia and people used to come there from afar. The Prophet (peace and blessings of Allah be upon him) used to go to these places and invite the people who came to the festival to Islam and Toheed. ${ }^{23}$

Then, as far as the voice can reach, it is addressing all.

Now the scope of preaching goes even further. Every living soul, i.e., understanding, feeling 
and intellect, etc., is addressed to the real life symbols that are present in it.

$$
\text { "ان هو الاذكر وقرآن مبين لينذر من كان حيا"24 }
$$

" This Qur'an is only a reminder and a clear word from Allah, that He may warn those who are alive."

$$
\text { "25" }
$$

Then, as far as the voice can reach, it is addressing all.

So that I may inform you and those to whom this message has reached The purpose is to preach to all the tribes and sects of Arabia. At this stage, you are reaching out to all the Arab tribes.

It is in the biography of Ibn Hasham that:

"O people! Of such and such tribe, I am the Messenger of Allah to you, who commands you to worship Allah and not to associate anything with Him. Believe in me, and believe in me. Abstain from those whom you associate with Him besides Allah, and believe in Me, and confirm me, and protect me until I make clear to you the message for which Allah has sent me". ${ }^{26}$

Then, in the last degree, the command of God is to address all human being:

$$
\text { "هذا بلغ للناس"27" }
$$

\section{This Qur'an is a message for all humanity}

The Holy Prophet addressed:

$$
\text { "28" }
$$

And we sent you as a bearer of good news and a warner to all people. He himself said which explains the following fact:

$$
\text { "29" }
$$

I was sent to all human beings, black and white

The meaning of this hadith is:

$$
\text { "اما انا فارسلت الى الناس كلهم كافه وكان من قبلى انما يرسل الى قومه"30 }
$$

In any case, I was sent to all human beings and the Prophets before me were sent only to their own nation.

It was only after this that preachers and messengers and preachers of Islam were sent to Arabia and abroad and letters of invitation to Islam were written to the emperors and sultans of the world. In addition to the Arabs, the students of Delam, Iran, Utihopia, and Rome converted to Islam, and the pagan Arabs, Jews, Christians, and Magi, all imbued with the bounty of truth, received enlightenment from his light in his time.

"The importance of Da'wah and preaching is as much emphasized in the Holy Qur'an as it is in the practice of the holy Prophet's life (peace and blessings of Allah be upon him). The word Da'wah has been used more than two hundred times in the Holy Qur' an and the word preaching has been used more than seventy times." 31

Let us see what strategy the Prophet of Islam used in fulfilling this duty.

\subsection{The overall strategy of Da'wah and preaching:}

The Prophet (peace and blessings of Allah be upon him) wanted not only to try one method of preaching, but to try every method possible. The real task of the Servant of the 
Universe was to proclaim the call of Islam to the whole world and to bring the whole world into the fold of Islam with all kinds of legitimate and correct means.

And wisdom is a comprehensive term and it includes all the practices that motivate the addressee to accept the truth, such as the opportunity to act, the addressee's psychology, the intellectual mastery, etc.

In order to fulfill this duty of the Lord, the Prophet (peace and blessings of Allah be upon him) adopted all the methods from sermons, exhortations, and from education to battlefield.

In the preceding lines, an attempt will be made to give them a glimpse of the method of preaching. The strategy of $D a^{\prime}$ wah and preaching of the Holy Prophet (PBUH) can be studied under these major headings and their sub-headings.

Verbal invitation and preaching and the strategies used in it.

Strategy in the early days of Islam (life of weakness and cosmopolitanism).

Migration strategy.

\subsection{Strategies used in verbal invitation and preaching:}

The mission of the Prophet was to preach Islam Wise preaching, invitation for doing good and prevention from bad is the backbone of the body of Islam, it is the foundation of Islam, the strength of Islam, the breadth of Islam and the success of Islam depends on it.

According to Professor Max Muller:

"Islam is in fact a missionary religion that has established itself on the basis of preaching. His progress depends on his strength and his life depends on him and the purpose of this Ummah is to establish Da'wah for Allah. And not only does its honor and greatness depend on it, but it also depends on its existence and survival. Therefore, there is no plan of action for the guarantee of its existence and survival except for the call to Allah"32

Language is a great, important and effective source of this invitation and preaching. Let us see what strategy, tact and politics, understanding and reasoning and which type of logic was used by the Holy Prophet in preaching through this medium.

\subsection{Call on the base of common Values:}

We see that instead of fighting or directly injuring the addressee, the Holy Prophet attempts to clarify the common aspects of the principles and rules on which there is unity. So that the substance of stubbornness and obstinacy may not be created and the desire to listen to the truth should come forward. And then he must be presented with the conclusions that must not deviate from the principles explained before, so that he may be inclined to accept them as his own.

The Holy Qur'an states:

$$
\text { "قل يأ اهل الكتب تعالو الى كلمه سواء بينا وبينكم"33 }
$$

O People of the Book! Come to what we have in common

In any case, the Prophet (peace and blessings of Allah be upon him) sought common ground between himself and his addressee and made it a point of contention. ${ }^{34}$

\subsection{The Wisdom of Banquet:}

The Prophet (peace and blessings of Allah be upon him) was commanded to: 


$$
\text { "وانذر عشيرتك الأقربين" }
$$

O Prophet, warn your relatives

"So he took another method of preaching in obedience to this divine command that he arranged a feast for his relatives. All the relatives did not come at the same time but came separately at different times and ate and left and there was no opportunity to preach. Then he would say again between the banquet and the meal! I want to tell you something after the meal, stay, waits, after the meal you told them why idolatry is bad, why monotheism is necessary, in the hereafter and the reckoning in the hereafter, etc. you told people a few basic things." 36

There is a proverb in Arabic: For the invitation, he adopted the strategy of banquet, because it is a popular saying in Arabic:

$$
\text { " الاحسان يستعبد الإنسان " }
$$

Kindness enslaves man Similarly, there is a well-known proverb in Arabic:

$$
\text { " اكلت تمرى و عصيت امرى"38 }
$$

It is wrong to eat my palm and disobey me

The Prophet (peace and blessings of Allah be upon him) adopted the strategy of feasting so that he would be kind to them and they would listen carefully and not be quick to refuse.

\subsection{Preaching according to the mental level of the addressee:}

The key to the success of Da'wah is that instead of philosophizing and meticulousness, one should instruct people in the known, that is, the straightforward and clear virtues which are generally known to all human beings or whose common sense helps to understand their goodness. Which is available to every human being, thus the appeal of the caller to the truth affects all the people and properties and you find a way to reach the heart from the ear of every listener.

That is to say, keeping in view the mental capacity of one's audience, preaching accordingly is first and foremost acceptability of the audience. The teachings of the Prophet are also a reflection of this strategy.

Therefore the Holy Prophet said:

$$
\text { " كلموا الناس بما يعرفونه و دعوا ماينكرون" }
$$

Talk to people according to what they understand, leave what they don't understand .

Anyway! The sciences and teachings of the ignorant world and the unseen preacher are wasted in the same way as the rain in the barren plains is neither absorbed nor the vegetation grows nor becomes a source of freshness.

Therefore, the Prophet (peace and blessings of Allah be upon him) said:

$$
\text { "كلمو الناس على قدر عقولهم" }
$$

Talk to people according to their intellect

Jesus Christ said:

$$
\text { "41" الاتعقو الجواهر باعناق الخنازير" }
$$

Do not tie jewels around the necks of pigs 


\subsection{Gradually Preaching:}

There are two important things to be preached in this regard: "Al-Ahm Falaham" and. Preaching should be done according to these to. The Prophet (peace and blessings of Allah be upon him) carried out his prophethood in this way, and his wisdom is such way of invitation is more acceptable for the addressee. ${ }^{42}$

According to Al-AQarb Fal AQarb :

The procedure for preaching will be the same as that adopted by the Holy Prophet and his Companions. He also said, that first preach in your family and tribe, then in the neighborhood, then in our own town, then in the nearest town, and so on. Thus, if in a short period of time we have spread the net of preaching and reformation in our country, then we should work in other near and far countries, leaving our immediate circles. If you prefer to work in remote areas, excluding those close to you, then there will be more demonstrations and exhibitions and the chances of success are very low.

Similarly, when the Prophet (peace and blessings of Allah be upon him) sent Mu'adh to Yemen, what he instructed him to do was to follow the same strategy which had resulted in first inviting the Jews and Christians to the Kalma Tayebah. If they accept it, then invite them to prayer, and if they accept it, then order them to pay Zakat and distribute it among the poor. 43

\subsection{Depending on the psychology of the addressee:}

The most important thing for the wisdom of preaching that the caller should always keep in mind is the ability and psychological condition of the addressee. For example, logical reasoning and philosophical discussions should be started with considering the mental capacity of the general audience. Or while talking to an intellectual, a colorless and unpretentious conversation should not be adopted.

There are some difficult requirements for the call to truth and some easy ones. And the difficult one, should not be mentioned by da'i, at the beginning, especially all the things that cause boredom and hatred.

In the hadith, the holy prophet said:

$$
\text { "يسروا ولا تعسروا وبشرو او لا تنغروا "44" }
$$

Make it easy and not difficult. Give good news and do not hate. Similarly, another hadith also sheds light on the strategy in terms of human psychology:

$$
\text { "انما بعثم ميسرين ولم تبعثو معسرين"45 }
$$

You have been sent as a facilitator and not as a troublemaker.

In the same way, psychological consideration includes not directly criticizing the beliefs and traditions of the addressee, because every nation is more or less attached to its own beliefs and traditions as a claimant to his rights. The way a claimant holds the truth in line with his beliefs should never be disrespected, in the spirit of righteousness, so that instead of correcting the intellectual causes of this false affiliation, he himself is directly attacked, with the result that the opponent would instead of accepting the invitation, he turns his back on it. $46 "$

The above mention instructions are clearly forbidden in the Holy Qur'an:

$$
\text { "و لاتسبوا الذين يدعون من دون الله فيسبوا الله عدوا بغير علم كذلك زينا لكل أمة عملهم" A7ll }
$$

And do not speak ill of those whom they call upon besides Allah, so that 
they go beyond the limits of knowledge and utter evil of Allah. In the same way, we have made good, their deeds in their eyes of every community.

In the same way, respecting the self-esteem of the leader of the nation also falls under this heading. Every human being, especially the elite, their Self-esteem is disgusting. If wisdom is treated with gentleness and respect and dignity, then it is first and foremost acceptable. The Holy Qur'an states that:

$$
\text { "اذهبا الى فرعون انه طغي. فقولا له قولالينا لعله يتذكر او يخشى" }
$$

Go both to Fir'aun (Pharaoh), for he has indeed transgressed all bounds, and speak to him a gentle word, so that he may take heed or be afraid.

\subsection{Findings according to the situation:}

Under this heading, we can study this strategy of the Prophet's temperament. That the addressee should be preached, when he is fully ready to listen, all-round and free from his distractions and free from any kind of mental and physical exhaustion and boredom. The eternal consequence of this strategy will be that this talk and invitation will continue to be intertwined in the heartbeat.

For this strategy, we find two types of light in the teachings of the Prophet. The Holy Prophet did not preach without a break.

He would shorten his sermons, advice, invitation and preaching.

It is narrated on the authority of Abu Wa'il that 'Abdullah ibn Mas'ood witnessed that the holy prophet used to preach every Thursday.

A man asked you: O Abu Abdullah! I want you to preach to us daily, you said! However, the thing that definitely discourages me from this is that I do not like to put you in boredom and I advise you in the same way as the Holy Prophet used to advise us out of fear of our boredom. ${ }^{4}$

In another place Hazrat Ibn Abbas (may Allah be pleased with him) said:

Every Friday tell the people about the religion and if you deny it just twice and if you do more than that (at most) three times do not make people board with this Holy Quran and I urge you every time, Do not let people be distracted by any of their conversations and do not start talking. And do not utter a word, then be silent, then admonish them when they command you, and they will listen to you with eagerness. ${ }^{50}$

In the same way, it is a sign of your preaching strategy that the speech should be stated in a concise and comprehensive manner so that the speech does not get boring and difficult to remember.

The Messenger of Allah (peace and blessings of Allah be upon him):

$$
\text { "كان لايطيل الموعظة يوم الجمعة" }
$$

did not prolong the sermon on Friday.

Another hadith of the Prophet (peace and blessings of Allah be upon him) is as follows:

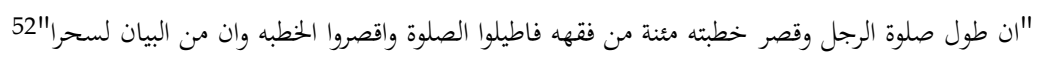

The length of a person's prayer and the shortness of his sermon is a sign of his wisdom, so lengthen the prayer and shorten the sermon. 


\subsection{Preaching as much as inner strength and power:}

This principle, full of wisdom and prudence, affirms the truthfulness of Prophet hood.

The Holy Prophet said:

"من راى منكم منكرا فليغيره بيده و ان لم يستطع فبلسانه فان لم يستطع فبقلبه وذلك اضعف الايمان" 53 ان 53 ان

Whoever of you sees evil, let him change it with his own hand, then if he does not have the power to do it, let him restrain it with his tongue, and if he does not have power over it, let him change it with his heart. And this is a weakest state of faith.

Just as goodness is preached, so is preventing evil from being a part of preaching. However, like all the rules of Shari'ah, there will be rules on the power and authority of every person who has as individual power.

There are two conditions for the obligation of the command to do well. One is to expect the addressee to accept and at least not to be afraid of any harm, and the other is that the addressee is not aware of it. And most of the time, where there is no knowledge, there is expectation of acceptance, and if there is knowledge, it often causes disgust.

" The hadith that you have just seen is based on affordability. Obviously, affordability and power are different in everything. ${ }^{54}$ "

\subsection{Perseverance and Consistency:}

For example in accordance with perseverance and determination Prophet said:

$$
\text { "والله يا عم لو وضعوا الشمس في يمينى و القمر في يسارى على أن اترك هذا الأمر ما فعلت حتى يظهره الله اوأهلك }
$$

By God, my uncle! If he puts the sun on my right hand and the moon on my left hand so that I can give up this da'wah, I will not give up until Allah Almighty makes Islam prevail or I perished.

In the same way, in the communication of the religion of Islam, in the preaching of each and every component, he said:

$$
\text { "بلغوعنى ولو آية" }
$$

Take it from me, even if it is just a piece of the Holy Qur'an

$$
\text { "فليبلغ الشاهد الغائب" }
$$

Let him convey the message of this religion to the present and absent

$$
\text { "نضر الله امرأ سمع عنا شيئفبلغه كما سمعه" } 58
$$

May Allah resuscitate the one who hears from us a religious thing and then conveys it as he heard it.

In the same way, for the addressees, he did heartfelt prayers. As the Prophet (peace and blessings of Allah be upon him) prayed after the storm of stubbiness of the people of Taif. 59

Similarly, in the battle of Uhud, when he was in a state of bloodshed and severe anguish, he prayed:

$$
\text { "اللهم اغفر لقومي فِإغم لا يعلمون"60" }
$$

\section{O Allah! Forgive my people, they do not know me.}

\subsection{To Restrain:}

In Makki's life of Holy Prophet, you and your loved ones endured a mountain of persecution, but in spite of all this, your policy and strategy was not to raise your hand, not to 
retaliate and not to take revenge. Syed Qutb Shaheed, a well-versed preacher, author of highprofile commentaries such as Zalal-ul-Quran and a member of Egypt's great revolutionary and da'wah movement, the Muslim Brotherhood, writes wisely on this strategy of Makki's life:

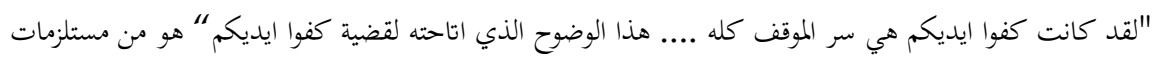

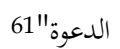

The secret of this invitation is hidden in "Kafwa Edekam" and all the

light that "Kofo Aydeekum" gave to the matter of preaching, of course

this light is one of the essentials of the invitation.

If the opponent gets into a quarrel, the caller does not gain anything from the quarrel, and the disadvantage is that the power of the caller should be expended in preaching the $d a^{\prime}$ wah and reforming the population is lost in this futile work. In any case, the work of invitation can be done with an emotionless heart. The only right step can be taken, which is not overwhelmed by emotions but by taking a good look at the opportunity. ${ }^{6}$

In Makki's life in particular and in all of Da'wah's life in general, he followed this strategy so that there would be no practical conflict.

"If a disbeliever does not have the power to eliminate or has the power to do so, but it causes great mischief or causes great harm. For example, if he is not able to continue the da'wah work after the loss, then he should act only if he considers the munkar to be bad from the heart. As mentioned in the hadith, you can see the example of the application of this principle that the Holy Prophet (saw) retained Abdullah bin Obai, the leader of the hypocrites. Because there were his supporters. If you had killed him, his whole congregation would have erupted (and a practical confrontation would have taken place) and he would have said about you that Muhammad kills only his companions" 63

However, in Makki's life, the master followed a strategy of avoiding practical confrontation so that the newborn bud of the da'wah process and the young plant of Islam would not be filed anywhere.

\subsection{Strategies for inclinations of heart of new Muslims towards Islam:}

At the beginning of Makki's life, the new Muslims suffer in the ruthless mill of misery but the believers froze like a strong rock in the face of these calamities. In these circumstances, the far-sighted Prophet (SWS) adopted the strategy of praying for the faith and guidance of the proud Quraysh and the pride of Makkah, and for Hazrat Umar (RA) so that the clouds of oppression would dissipate and Islam would gain strength and glory.

$$
\text { "اللهم! ايد الاسلام بعمر بن الخطاب رضى الله عنه "64 }
$$

\section{O Lord of Islam, grant strength from Umar bin Khattab}

Regarding the Islam of Hazrat Umar (RA), Hazrat Ibn Abbas (may Allah be pleased with him) said: On your Islam, Gabriel Amin asked the Messenger of Allah (May peace be upon him): O Muhammad, the people of heaven are happy with his Islam.

Allah Almighty honored Islam from him and helped the weak new Muslims from him. Hazrat Ibn Masood (may Allah be pleased with him) said:

Omar's conversion to Islam was a cause of honor, his migration was of highest honor, and his reign was of mercy, by God! You could not openly offer prayers in the House of Allah 
until Hazrat Umar (RA) converted to Islam ${ }^{65}$

\subsection{Migration Strategies in Makki Life:}

Migration was a supreme example of the Prophet's prudent and his wise strategy. There were two wisdoms to this migration.

Salvation and deliverance from the oppression of the infidels

The expansion of the duty of preaching, seeing the helplessness of the weak in Makkah, made the zeal of the unscrupulous infidels tremble even more.

Hundreds of people in Makkah had converted to Islam as a result of these preaching activities, but they were forced to flee the country due to the persecution of the Quraysh. They left for Ethiopia on the advice of the Prophet (peace and blessings of Allah be upon him). The emigration of these oppressed Muslims provided an opportunity for them to spread the word of Islam throughout the journey and thus spread the Islamic movement in both Yemen and Ethiopia. 66

\subsection{Hidden Preaching:}

Similarly, before the revelation of the verse "فاصدع بما تومر" you secretly preached your wisdom.67

And those who believed were also instructed to conceal their faith so that they would be safe from the persecution of the polytheists of Makkah and they would be secretly converted to Islam in Dar-al-Arqam and the teachings of the Prophet would be made known there.

\subsection{Emphasis on faith:}

Since the Makki life was in the early days of Islam and people were repenting of disbelief and polytheism, the work of faith was more in Mickey's life and two matters were most important in faith.

\section{Toheed}

\section{Believe on life after death}

And the same subject is more prevalent in the Surahs revealed in the Mickey era, hich are Surah Al-Baqarah, Al-Imran, Al-Nisa Al-Maida, Al-Anfal, Al-Tawbah, Al-Hajj, Al-Noor, Al-Ahzab, Al-Qatal, Al-Fatah, Al-Hujurat, Al-Hadid, Al-Mujadilah. These twenty-three (23) Surahs are Madani. The rest of the Qur'an is Makki. Now in civil life, acts of prayer, fasting, Hajj, Zakat, Jihad, etc. have become obligatory. To important subjects in theses Mkkis Surahs are Toheed and believe on life after death ${ }^{68}$.

\subsection{Discussion results:}

The basic Qur'anic prophetic strategy has these three principles: intellect and wisdom, good sermons and attractive arguments.

For theologians, these three principles are the same ones that are usually used in logical reasoning.

The Holy Prophet (peace and blessings of Allah be upon him) did not remained confined with one method of preaching, but tried every method possible and spread the light of Da'wah.

Instead of fighting or directly hurting the addresses, the Holy Prophet tried to explain with logical the common aspects of the principles and rules on which there is unity.

The key to the success of Da'wah-e-Haq is that instead of philosophical and meticulous discussions, man should teach people through the well-known sayings, through 
straightforward and clear virtues that are known to all human beings, or use the common sense to make them understand goodness, which every human being gets.

Since Islam was in its infancy in Makki life, the principles of $D a^{\prime}$ wah and preaching that have been followed include the emphasis on Kafu al-Ayyid, the strategies for inclinations of heart of new Muslims towards Islam, secrecy, migration, belief and faith were followed. This research is done with the help of various verses and Ahadith, enlightened the Makki life of The Holy Prophet (peace and blessings of Allah be upon him) and His all strategies are still useful for all ages. Peace, prosperity and brotherhood can be promoted in the entire world by implementing His $\mathrm{Da}$ 'wah strategies.

This work is licensed under a Creative Commons Attribution 4.0 International License.

\section{References}

1 Zubaidi,SyedMurtaza,Tajulroos,PublisherDarulfikar,Labnan,Bearoot,Vol.8,P,322

${ }^{2}$ Asfahni,Ragib,HussainbinMuhammad,Mufradat-li-alfazilquran,Krachi,P,172

${ }^{3}$ Urdu Daira Maarif Islamia,Dawat,V,9,P344

4 Ibn Manzoor, Afriqi Muhammad bin Mukaram, Lisan ul Arab, Publisher,Darulahya Alturas-ul-Arabi,Tjauluroos, V,12,P,8

${ }^{5}$ Noumani,Shibli,Seerat-un-Nabi,Publisher,Islami,kutab Khana, V4,P,205

${ }^{6}$ Ibid:P,205

${ }^{7}$ Farooz-u-dim,Molvi,Farooz-ul-Lugaat,Publisher,Farooz and sons,Lahore,P,557

${ }^{8}$ Nayer,Noor -Ul-Hassan,Noor-ul-Lugat,V2,P1227

${ }^{9}$ Encyclopidia of Britannica,V11,P305

${ }^{10}$ Qomi English Urdu Dictonory,Publisher Qomi Zuban Islamiabad,P1970

${ }^{11}$ Longman Dictionary of contemporary English,P,269

12 Abu dawood, Sulaman bin Ashshat,Sunan Abi Dawood,V1,P,225

13 Mansoorpuri, Muhammad Sulaman,Qazi,Rahmat-ul-lilalamin,Publisher, Islami kutubkhana,Lahore,V1,P225

14 AlQuran:16,125

${ }^{15}$ Alosi, Mahmood,Rohulmahani,V14,P661

${ }^{16}$ AlQuran:16,125

17 Shibli,Seerat-un-Nabi,Publisher,Islami,kutab Khana,V4,P,207

18 AlQuran:26,214

19 Usmani, Shabir Ahmed,Tafseer Usmani,Iqra Ashrafia Company,Lahore,P,792

20 AlQuran:111,1-2

21 AlQuran:42,7

22 Shibli,Seerat-un-Nabi,Publisher,Islami,kutab Khana,V4,P,208

23 Mansoorpuri, Muhammad Sulaman,Qazi,Rahmat-ul-lilalamin,Publisher, Islami kutubkhana,Lahore, V1,P,48

${ }^{24}$ AlQuran:36:70

${ }_{25}$ AlQuran: 6,19

${ }^{26}$ IbnHasham,MuhammadBinAbdulMalik,Alseerat-un-Nabvia,Idara Islamiat,LahoreV,1,P,282 
27 AlQuran: 14,54

28 AlQuran: 34,28

${ }^{29}$ Ahmed Bin Hambal,Alimam,Musnad,V4,P416

30 Ibid:25,12

31 Tayab, Muhammad,Qari,Islam main dawat -o-Tableeg ka usool Qawaid,P,4

32 Israr ahmed,Dr,Dawat Ilalah ki Zarorat-o-Ahmiat,Injaman Kudam-ul- Quran ki Zaroorat-o- Ahmiat,Publisher, Injaman Khudam-ul-Quran,P6

${ }^{33}$ AlQuran: 3,64

34 Islahi, Ameen Ahsan,Dawat deen or is ka tareeqa kar,Publisher,Markazi Maktaba Jamat Islami,P,147

35 AlQuran: 26,214

36 Hameedullah,Dr, Dr Hameedullah Ki Bahtreen Tahrerin,Publisher,Becon Books Lahore,P231

37 Tamimi ,Abdul wahid ,Gara-ul-Hikam-wa-Duraul-kalim,V1,P385

38 Ibid:p,385

${ }^{39}$ Manavi,AbdulRaoof,Alimam,Kunooz-ul-HaqaiqMinHadeesKharil Khalaiq,Publisher Daraul marif Multan,P504

40 Ibid:P504

41 Tayab, Muhammad,Qari,Islam main dawat -o-Tableeg ka usool Qawaid,P,54

42 Nadvi, Syed Sulman,Islam ka Nizam-e-Dawat -o-Tableeg,Publisher Dawah Academy Islamabad,P16

${ }^{43}$ Bukhari, Muhammad Bin Ismail,Aljamihusahih,V6,P64

44 Ibid:V1,P25

45 Ibid:V1,P25

${ }^{46}$ Islahi, Ameen Ahsan, Anbiya Ka Tarz Istadlal,P37

${ }^{47}$ AlQuran: 6,108

48 AlQuran: 20,44

49 Bukhari, Muhammad Bin Ismail,Aljamihusahih,V10,P25

50 Ibid:V5,P195

${ }^{51}$ Kunooz-ul-HaqaiqMinHadeesKharil Khalaiq, P5421

52 Alqushari,Muslim bin Hajaj,Alshaih-lil-imamMuslim,V3,P12

${ }^{53}$ Albagvi ,Hussain Bin Masood,Mishkat-ul-Masabih,P432

54 Thanivi, Ashraf Ali ,Hakeem-ul-Umat,Alifazat -ul-Yao mia,V4,Q180

55 Alseerat-un-Nabvia, V,1,P,266

56 Bukhari,Aljamihusahih,V5,P126

57 Ibid: V5,P126

58 Tirmazi,Muhammad Bin Isa, Aljamih-u- Tirmazi,V2,P90

${ }^{59}$ Alhazrami,AlShaikh,Noor-ul-Yaqeen-fi-seerat-ul-syed-ul-

Mursaleen,Publisher,Qadeemi Kutub Khana,P,71

60 Alqushari, Muslim Bin Hajaj, Alsahih ALmuslim,V5,179

${ }^{61}$ Almisri, Syed Muhammad Qutab, Kayfa NadhoNas,P19

62 Mudodi, Syed Abul Ahla, Usloob Dawat, Manshoorat,Lahore,P20

63 Ibn tamia Ahmed Bin Abdul Haleem,Fatawa Ibn Tamia,P302

${ }^{64}$ Muglatai, Alaudinhanfi,Alishar-Ila-Seerat Musatfa,P149

65 Noor-ul-Yaqeen-fi-seerat-ul-syed-ul- Mursaleen, ,P,63

66 Noumani, Shibli, Seeratunbi, V4,p,219

67 Tirmazi,Abdul Shakoor ,Syed,Dawat-o- Tablig- Ki sharhi Hasiat,P,44 
${ }^{68}$ Ibid:P,89 